\title{
EUROPEAN COURT OF HUMAN RIGHTS PRACTICE AS A SOURCE OF LAW
}

Yevheniia S. Kaliuzhna

Postgraduate student of Odesa State University of Internal Affairs

1 Uspenskaya Str., Odesa, Ukraine, 65014

https://orcid.org/0000-0002-8734-9891

evgewa9494@gmail.com

Abstract. The urgency of the research is stipulated by the necessity to study the European Court of Human Rights practice as a source of law at the regional level, which affects the development of national legal systems. The purpose of the article is to elucidate the European Court of Human Rights practice as a source of law for member states to the Convention for the Protection of Human Rights and Fundamental Freedoms (on the examples of individual decisions). The research is based on the understanding of law as a dynamic social and cultural phenomenon having a specific content and is closely related to human dignity, human rights and justice. Legislation is only one form of law that can exist outside the prescriptive texts, which requires the use of the hermeneutic method and content analysis of the European Court of Human Rights decisions.

The article finds out that the European Court of Human Rights is one of the most effective institutions for human rights implementation. Applying the provisions of the Convention for the Protection of Human Rights and Fundamental Freedoms, which was adopted in 1950, through a dynamic interpretation, the European Court of Human Rights ensures the effectiveness and efficiency of this international treaty, revealing the content in the aspect of modernity. States parties to the Convention for the Protection of Human Rights and Fundamental Freedoms are obliged to comply with the European Court of Human Rights decisions, which (the court) always follows its practice, ensuring legal certainty and the rule of law. This allows considering the European Court of Human Rights a subject forming legal doctrines at both regional and national levels. The materials of the article can be used for scientific research of the European Court of Human Rights practice as a source of law at the regional level, which affects national legal systems. The main provisions of the article can be used to justify the study of ECHR practice by lawyers as well as law students and civil servants.

Keywords: European Court of Human Rights, human rights, rule of law, source of law, European Court of Human Rights practice. 


\section{INTRODUCTION}

Today, the state of human rights implementation is the crucial indicator of the public authorities' activities effectiveness. The fundamental task of the state is to ensure human rights in a civilized society. At the same time, if in the first half of the twentieth century the issue of human rights had a predominantly national character, then since the second half of the twentieth century it has acquired an international character. Human rights have become an important axiological component of a democratic society, which also includes "human dignity, justice, the rule of law, and constitutional democracy" (Kuchuk et al, 2019).

With the adoption of the Universal Declaration of Human Rights (1948) the concept of human rights began to take shape, the main features of which are the recognition of the natural, inalienable, fundamental nature of human rights, human rights should be equal and have priority over the law (they exist regardless of their enshrinement in the text of the law).

However, the changes that have taken place in society since the second half of the twentieth century could not but affect the theory of human rights. The rapid development of the information sphere, globalization and European integration has become the factors that have influenced the development of human rights. Thus, "a number of lawyers claim the emergence of the fourth generation of human rights - somatic rights at the present stage of society development" (Ivanii et al, 2020).

One cannot but agree that the development of business has become an important factor in changing the concept of human rights, in particular, in the context of the verticality of human rights (the addressee of human rights is not only the state but also business) (Orlova et al, 2020).

Relevant institutions' activities, as well as their respond in a timely manner to social change are crucial to monitor the implementation of human rights. One of such institution is the European Court of Human Rights (ECHR) established within the Council of Europe. As G. Ulfstein, M. Ruud and A. Follesdal (2020) noted, the institutions for ensuring the effectiveness of the Convention for the Protection of Human Rights and Fundamental Freedoms play an important role in European and international law order.

It is the ECHR that ensures the relevance of the Convention for the Protection of Human Rights and Fundamental Freedoms provisions (1950), the conformity of its norms with the present time. Herewith, the interpretation of the ECHR provisions should be consistent with "the general spirit of the Convention, an instrument designed to maintain and promote the ideals and values of a democratic society"(ECHR, 1989).

The ECHR, while interpreting the Convention (1950), is a kind of subject of creation of the legal doctrines in the field of human rights (Inal, 2020), which affect the legal systems of the states-parties to this Convention. Thus, it is important to know the activities of the ECHR as an institution influencing the development of national legal systems of a number of states.

Therefore, the aim of this study is to elucidate the practice of the ECHR as a source of law for states-parties to the Convention for the Protection of Human Rights and Fundamental Freedoms (on the examples of individual decisions). 


\section{MATERIALS AND METHODS}

The research is based on understanding of law as a dynamic social and cultural phenomenon that has a specific content and is closely related to human dignity, human rights and justice. Legislation is only one of the forms of law that can exist outside the prescriptive texts, for example, in the form of principles of law, we will mention, in particular, the principle of the rule of law.

The paper takes into account the approach according to which the provisions of the Convention for the Protection of Human Rights and Fundamental Freedoms are implicit and acquire their meaning through their interpretation by the ECHR, therefore, the source of law is not the decisions of the ECHR but the ECHR's provisions (however, let us accentuate that these provisions acquire particular content by means of the ECHR's practice). In this case, the interpretation of the Convention provisions by the ECHR is carried out in accordance with the principle of dynamic interpretation. The obligation of the States-parties to the Convention for the Protection of Human Rights and Fundamental Freedoms (1950) is to comply with ECHR decisions in cases concerning them, as well as the consistency of ECHR practice, which provides legal certainty, stipulates the necessity of national states to follow legal provisions formed by the ECHR changing their legislation.

The study of individual decisions of the ECHR was carried out using a hermeneutic method and the content analysis method, which allowed to take into account the specific circumstances of the case, the peculiarities of national legal systems, presence of discretion in public authorities while regulating public relations and the necessity to understand the Convention as a contract on human rights and fundamental freedoms collective implementation. (ECHR, 1978) One of the fundamental provisions of the study is that the discretion of public authorities as to law and order insurance has certain limits, which are determined, among other things, by the essential nature of human rights, and the principle of the rule of law.

In deciding the case, the ECHR takes into account the national aspect, but also pays attention to the international (universal and regional) aspects, analyzing the presence or absence of consensus of states concerning the issue solving.

The use of logical methods of analysis and synthesis ensured the reliability of the obtained results of the study.

The study is based on an analysis of about 50 judgments of the European Court of Human Rights in cases against different states.

\section{RESULTS AND DISCUSSION}

Beginning with the second half of the twentieth century, when the international system of human rights provision started taking shape, the institutions monitoring implementation of certain international treaties were established, influencing the formation of established practice of public relations legal regulation. The ECHR is one of the most effective human rights' ensuring institutions. Applying the provisions of the Convention for the Protection of Human Rights and Fundamental Freedoms, which was adopted in 1950, through a dynamic 
interpretation, the ECHR ensures the effectiveness and efficiency of this international treaty, revealing the content in the aspect of modernity. States-parties to the Convention for the Protection of Human Rights and Fundamental Freedoms are obliged to comply with the ECHR's decision, which (the court) always follows its practice, ensuring legal certainty and the rule of law. This allows considering the European Court of Human Rights a subject forming legal doctrines at both regional and national levels.

This determines the expediency of: 1) purposeful study of the practice of ECHR, in the context of its impact on national legal systems and international law, by lawyers; 2) perception of ECHR practice as a source of law and its study in the process of training lawyers in higher legal institutions; 3 ) the practice of ECHR study by civil servants who are supposed to ensure human rights.

The ECHR has been established to monitor the implementation of the Convention for the Protection of Human Rights and Fundamental Freedoms provisions. The decisions it takes are binding on the States concerned. An important task of the ECHR is to ensure the implementation of the rule of law and legal certainty, which makes it impossible to make radically opposite decisions in cases with similar circumstances. As K. Nikonorova (2019) rightly points out, the ECtHR does change its legal position only in exceptional cases, referring to the development of law in the context of a new social and economic situation. Therefore, the decisions of the ECtHR are based on precedent. Every decision of the ECtHR, all its practice is aimed at the Convention principles implementation.

"It is easy to see that the Convention norms are general in nature, and human rights are mostly stated in an abstract, evaluative form. However, given that it is impossible to formulate an exhaustive list of rights and forms of their implementation in the text of the Convention, the true meaning of the Convention is clarified only after interpretation and application in court decisions" (Yagunov, 2010).

This allows us to talk about the precedent nature which is inherent in the ECHR decisions. However, the issue of whether the judgments of this Court are precedent is debatable in the legal literature and should be examined separately; however, few deny the existence of wellestablished ECHR practice and the Court's follow-up to similar findings. Some aspects of this topic are fairly systematically covered by S. Pattinson (2015), including the correlation between precedent at the national level and precedent at the regional level. V. Zavhorodnii (2015) described various approaches to understanding the nature of ECHR decisions, indicating the arguments of each party. At the same time, within the framework of our study, the described issue is not significant based on the binding nature of ECHR decisions (in particular, in the context of measures taken by the state to further prevent violations of the Convention for the Protection of Human Rights and Fundamental Freedoms) and that is why we do not join this discussion.

In the framework of our study, it should also be noted that there is no single mechanism for implementing the ECHR decisions among the states parties to the Convention for the Protection of Human Rights and Fundamental Freedoms (1950).

Thus, it should be noted that on July 14, 2015, the Constitutional Court of Russia issued a ruling on the implementation of ECHR decisions in the Russian Federation, according to which if there is a contradiction between the ECHR decision and the Russian Constitution, 
priority is given to the Constitution. In such cases Russia will refuse to comply with the "disputed" decisions of the Court. The Constitutional Court of Russia will assess the constitutionality of ECHR decisions on the basis of an appeal from public authorities (Ministry of Foreign Affairs of Ukraine, 2015).

Ukraine has adopted the Law "On Enforcement of Judgments and Application of the European Court of Human Rights Practice” (2006), according to which Ukrainian courts apply the Convention and the Court practice as a source of law and which determines the procedure for enforcement of ECHR decisions and taking general measures.

Researchers also note problematic aspects of the ECHR practice application in Turkey. For example, Tuba Inal (2020) elucidated the role of the ECHR in changing gender norms in Turkey, emphasizing that Turkey is one of the states where the most frequently human rights are violated (based on the analysis of the number of appeals to the ECHR) and where patriarchal culture still prevails, which is protected, including by the judiciary. In the study, the author elucidates the long-standing resistance of courts and other institutions of the Turkish state to adopt an important rule to ensure equality of human rights - the right of a married woman to keep her name, as well as the changes in Turkish national legal system that became possible due to ECHR practice (Inal, 2020), in particular, these are cases of violation of Art. 8 and Art. 14 of the Convention for the Protection of Human Rights and Fundamental Freedoms by Turkey: Ünal Tekeli v. Turkey (2004), Leventoğlu Abdülkadiroğlu v. Turkey (2013), Tuncer Güneş v. Turkey (2013), Tanbay Tüten v. Turkey (2013).

In the context of our study, the conclusions of Tuba Inal (2020) on the formation of a discourse in Turkey by individual judges that the issue of preserving premarital surnames by women belongs to the realm of human rights and not to the issue of family or Turkish unity are important. This further provided the opportunity to implement ECHR decisions.

"While the deeply patriarchal state and society is resisting internalization, the developments in this case demonstrate that even on the subject of gender norms, the hard-shell case of norm diffusion, courts are important actors perforating the shell, changing the discourse, and pushing the process forward" (Inal, 2020).

Crucial for understanding the essence of human rights, in particular the right to freedom from tortures was the case of Ireland v. the United Kingdom (1978), in which the ECHR formulated a number of provisions regarding the delimitation of torture, inhuman and degrading treatment.

The concept of a "minimum level of cruelty" was formulated in this case: only the achievement of this level by treatment or punishment indicates the presence of torture, inhuman and degrading treatment or punishment and indicates a violation of Art. 3 of the Convention for the Protection of Human Rights and Fundamental Freedoms.

The ECHR noted the absolute nature of the right enshrined in Art. 3 of the Convention for the Protection of Human Rights and Fundamental Freedoms. No emergency, even a threat to the life of the nation, can justify the application of illicit treatment or punishment to a person.

The ECHR, in the case mentioned above, assessed, among other things, the "five techniques" of interrogation: standing by a wall, covering one's head with a cap, exposing oneself to noise and depriving oneself of sleep, food and drink, and interpreted them as inhuman and degrading. 
At the same time the interpretation of these methods is fully consistent with the understanding of torture in modern conditions. That is why it is worth noting the attempt to reconsider this case at the request of Ireland. "The applicant Government requested a revision of the Court's judgment of 18 January 1978 to the effect that the use of the five techniques of interrogation in depth amounted to a practice not merely of inhuman and degrading treatment but of torture within the meaning of Article 3 of the Convention" (ECHR, 2018). However, the ECHR noted that the material provided by the applicant did not meet the requirements set for review.

The case of A. v. the United Kingdom (ECHR, 1998) is worth mentioning in the context of Art. 3 of the Convention for the Protection of Human Rights and Fundamental Freedoms. This case is important because of the interpretation of such a feature of human rights as equality, as well as for the perception of the rights of the child.

According to the circumstances of the case, the stepfather beat A. with a stick (repeatedly) for the purpose of upbringing, because the child was disobedient, did not respond to the parents' remarks, and violated discipline at school. The stepfather was accused of assault with bodily injuries. However, most jurors pleaded the stepfather not guilty to assault, which resulted in bodily harm.

A. appealed to the ECHR with a complaint of violation of Article. 3 of the Convention for the Protection of Human Rights and Fundamental Freedoms by the UK, as the public authorities did not protect him from degrading treatment by his stepfather.

It should be noted that the legislation in force at that time provided for the possibility of parents to legally punish the child. "Parents or other persons in loco parentis are protected by the law if they administer punishment which is moderate and reasonable in the circumstances. The concept of "reasonableness" permits the courts to apply standards prevailing in contemporary society with regard to the physical punishment of children" (ECHR, 1998).

In the Court's view, such legislation does not comply with the rule of law principle, does not provide the child with effective measures of restraint on the part of the parents. As a result, the ECHR found a violation of Art. 3 of the Convention for the Protection of Human Rights and Fundamental Freedoms and awarded satisfaction in the amount of ten thousand pounds and twenty thousand - compensation for costs.

Let us note that the government has agreed that the legislation in this area should be changed. As we can see, it was due to the ECHR that national legislation was changed. In fact, this decision helped to recognize that a child is also endowed with inalienable, natural rights on an equal footing with an adult. Traditions and legislation, if they do not meet the requirements of the rule of law, cannot be a regulator of public relations. Human rights have priority in the event of a contradiction between human rights and the law.

The ECHR also dealt with cases involving a legally and morally ambiguous issue, euthanasia. These include: Sanles Sanles v. Spain (ECHR, 2000), Pretty v. the United Kingdom (ECHR, 2002), Haas v. Switzerland (ECHR, 2011), Koch v. Germany (ECHR, 2012), Gross v. Germany. Switzerland (ECHR, 2014).

In general, the analysis of euthanasia decisions leads to the conclusion that the ECHR adheres to the issue of neutrality in such cases, analyzes the national legislation of the 
defendants in a particular case (given the lack of consensus within Europe on euthanasia and the wide limits of public authority discretion).

At the same time, it is worth focusing on the judgment in Pretty v. the United Kingdom (ECHR, 2002), in which the ECHR stated that Art. 2 of the Convention for the Protection of Human Rights and Fundamental Freedoms cannot be interpreted as including a negative aspect. This article does not grant the right to die, it does not provide for the possibility of creating the right to self-determination, that is, to give a person the right to choose death and not life.

It should be noted several ECHR decisions that have significantly influenced the improvement of the Ukrainian legislation. First of all, let's mention the case of Nataliya Mikhaylenko v. Ukraine (ECHR, 2013), which influenced changes in the Ukrainian civil and civil procedure legislation. By the circumstances of the case, the incapacitated applicant applied to the national courts for reinstatement of her legal capacity. The national courts did not accept her application, as the Ukrainian law did not provide for the possibility of an incapacitated person to go to court on his own (only the guardian had such an opportunity). In addition, the legislation did not provide for an automatic review of the decision on incapacity for a certain period of time and the decision itself did not contain the terms of limitation of legal capacity.

Nataliya Mikhaylenko appealed to the ECHR with a complaint about Ukraine's violation of Art. $6 \S 1$ and Art. 13 of the Convention for the Protection of Human Rights and Fundamental Freedoms, due to the impossibility of directly filing an application with a court to restore her civil capacity and discrimination due to lack of direct access to court. Let us note that the ECHR considered the application only for breach of access to a court right (Article $6 \S 1$ ).

ECHR (2013) noted that the right of access to a court is not absolute and it might be limited based on the necessity for state regulation, so the implementation of this right might change due to changes in legislation. In this matter, the national government possesses certain discretion. However, restrictions on the right of access to a court cannot infringe on the substance of the right itself. Herewith, the legitimacy of the restriction of the right of access to court is subject to a three-part test: the restriction should be established by law, have a legitimate purpose and be proportionate.

The ECHR (2013) reiterated that the Convention for the Protection of Human Rights and Fundamental Freedoms guarantees rights that are not illusory, theoretical, but that human rights are practical and effective. This is especially true of the right of access to court, given that a fair trial plays an important role in a democratic society.

It is also important for the ECHR to take into account the comparative analysis of the legislation of European states on access to court for incapacitated persons to determine the existence of consensus among states on this issue. "The Court notes that the approach pursued by domestic law, according to which an incapacitated person has no right of direct access to a court with a view to having his or her legal capacity restored, is not in line with the general trend at European level. In particular, the comparative analysis conducted in the case of Stanev (cited above, §§ 88-90) shows that seventeen of the twenty national legal systems studied provided at the time for direct access to the courts for persons who have been declared fully incapable (ibid., § 243)» (ECHR, 2013). 
Taking into consideration the abovementioned, the ECHR's conclusion that the applicant had been denied justice and, accordingly, a violation of Art. $6 \S 1$ took place, is quite logical.

The improvement of criminal procedure legislation in Ukraine was significantly influenced by the case of Volokhy v. Ukraine. The applicants complained to the ECHR of a violation of Art. 8 and of Art. 13 of the Convention for the Protection of Human Rights and Fundamental Freedoms due to the state's failure to respect their right to respect for correspondence, and the lack of effective remedies to declare interference with their rights illegal and to obtain compensation (ECHR, 2006).

In the circumstances of the case, the militia confiscated the applicants' mail (the investigation action was carried out in accordance with the procedure provided for by the Ukrainian law). However, ECHR (2006), examining whether the law clearly established the circumstances in which law enforcement agencies could review correspondence, concluded that Ukrainian legislation did not define with sufficient clarity the limits and conditions for the authorities to exercise their discretion on the issue under consideration. It was emphasized that the phrase "according to the law" not only refers to national law, but is also related to the requirement of the quality of "the law", that is the requirement to comply with the "the rule of law" principle.

The two cases mentioned above concerning Ukraine, as well as the case of A. v. The United Kingdom allows drawing an important conclusion, especially for the post-soviet states:

1. law is not identified with the law and might have other forms of manifestation, for example, the principle of the rule of law;

2. a reference to a prescription of legislation is not enough to restrict human rights; such a restriction should be carried out for a legitimate purpose and be necessary within a democratic society (it should be proportionate);

3. the existence of a prescription of the law does not indicate the existence of normativeness of the rule established by the prescription: the law should comply with the rule of law principle, and not to encroach on the essential nature of human rights.

4. restricting human rights, public authorities should not only refer to the article of the law, which provides for their authority to act accordingly, but also to justify their actions (especially important is the reasoning of the decision by national courts, which is one of the factors of legitimacy).

\section{CONCLUSIONS}

Thus, in monitoring States' compliance with the provisions of the Convention for the Protection of Human Rights and Fundamental Freedoms, the ECHR interprets the provisions of the Convention, filling them with meaning. At the same time, the ECHR usually does not deviate from the legal provisions formulated by it (in order for the ECHR to change its position, it is necessary the significant change of the situation, building consensus on the issue within the States Parties to the Convention, etc.). Therefore, States-parties to the Convention should study the practice of the ECHR, which significantly influences changes in their national legislation, serving as the source of law. Thus, the Convention for the Protection of Human Rights and Fundamental Freedoms and the ECHR practice, which 
reveals the implicit nature of the provisions of the Convention, should be considered as the source of law at the regional and national levels.

The abovementioned allows us to formulate the following provisions, having a recommendatory nature:

1. the ECHR practice should be the subject of targeted research by scholars, in the context of its impact on national legal systems and international law (both universal and regional);

2. the perception of ECHR practice as the source of law necessitates its study in the process of training lawyers in higher legal education institutions, which requires the introduction of the relevant academic subject into the educational process;

3. the study of ECHR practices should be a mandatory element of the civil servants training, who should implement human rights.

\section{REFERENCES}

Council of Europe. Convention for the Protection of Human Rights and Fundamental Freedoms. (1950).

European Court of Human Rights. (1978). Case of Ireland v. the United Kingdom (Application no. 5310/71).

Retrieved from https://www.refworld.org/cases,ECHR,3ae6b7004.html

European Court of Human Rights. (1989). Case of Soering v. the United Kingdom (Application no.

14038/88), Retrieved from http://hudoc.echr.coe.int/eng?i=001-57619

European Court of Human Rights. (1998). Case of A. v. the United Kingdom (Application no.

100/1997/884/1096). Retrieved from http://hudoc.echr.coe.int/fre?i=001-58232

European Court of Human Rights. (2000). Case of Sanles Sanles v. Spain (Application no. 48335/99).

Retrieved from http://hudoc.echr.coe.int/eng?i=001-22151

European Court of Human Rights. (2002). Case of Pretty v. the United Kingdom (Application no. 2346/02).

Retrieved from http://hudoc.echr.coe.int/fre?i=003-542432-544154

European Court of Human Rights. (2004). Case of Ünal Tekeli v. Turkey (Application no. 29865/96).

Retrieved from http://hudoc.echr.coe.int/eng?i=001-67482

European Court of Human Rights. (2006). Case of Volokhy v. Ukraine (Application no. 23543/02).

Retrieved from http://hudoc.echr.coe.int/eng?i=001-77837

European Court of Human Rights. (2011). Case of Haas v. Switzerland (Application no. 31322/07).

Retrieved from http://hudoc.echr.coe.int/rus?i=001-102940

European Court of Human Rights. (2012). Case of Gross v. Switzerland (Application no. 67810/10).

Retrieved from http://hudoc.echr.coe.int/rus?i=001-146780

European Court of Human Rights. (2012). Case of Koch v. Germany (Application no. 497/09). Retrieved

from http://hudoc.echr.coe.int/rus?i=001-112282

European Court of Human Rights. (2013). Case of Leventoğlu Abdülkadiroğlu v. Turkey (Application no.

7971/07). Retrieved from http://hudoc.echr.coe.int/eng?i=001-119957

European Court of Human Rights. (2013). Case of Nataliya Mikhaylenko v. Ukraine (Application no.

49069/11). Retrieved from http://hudoc.echr.coe.int/eng?i=001-119975

European Court of Human Rights. (2013). Case of Tanbay Tüten v. Turkey (Application no. 38249/09).

Retrieved from http://hudoc.echr.coe.int/eng?i=001-138892

European Court of Human Rights. (2013). Case of Tuncer Güneş v. Turkey (Application no. 26268/08).

Retrieved from http://hudoc.echr.coe.int/eng?i=001-126133

European Court of Human Rights. (2018). Case of Ireland v. the United Kingdom (Application no. 5310/71).

Retrieved from http://hudoc.echr.coe.int/eng?i=001-181585

Inal, T. (2020). The role of the European court of human rights in changing gender norms in Turkey: the case of women's maiden names. Turkish Studies, 21 (4), 524-556. DOI: https://doi.org/10.1080/14683849.2 019.1665466

Ivanii, O., Kuchuk, A., Orlova, O. (2020). Biotechnology as Factor for the Fourth Generation of Human Rights Formation. Journal of History Culture and Art Research, 9(1), 115-121. DOI: http://dx.doi.org/10.7596/

taksad.v9i1.2540 
Kuchuk, A.M., Serdiuk, L.M., Zavhorodnia, Y.S. (2019). Modern law education in the context of natural understanding of law. The Asian International Journal of Life Sciences, 21 (2), 359-370.

Ministry of Foreign Affairs of Ukraine. Commentary on the Decision of the Constitutional Court of the Russian Federation on the Application of ECtHR Decisions (2015). Retrieved from https://chicago.mfa.gov. ua/news/3732-komentar-mzs-ukrajini-shhodo-postanovi-konstitucijnogo-sudu-rf-pro-zastosuvannyarisheny-jespl-ukrros

Nikonorova, K. (2019). European Court of Human Rights Practice and its Value to Administrative Justice. Economics. Finances. Law, 12 (3), 17-20.

On the Implementation of Decisions and the European Court of Human Rights Practice Application № 3477-IV. (2006).

Orlova, O., Kuchuk, A., Ivanii, O. Business and Human Rights: Dialectics of Interaction. Advances in Economics, Business and Management Research, 2020, 129, 56-62.

Pattinson, S. (2015). The Human Rights Act and the doctrine of precedent. Legal Studies, 35(1), 142-164.

Ulfstein, G., Ruud, M., Føllesdal, A. (2020). The European Convention on Human Rights and other parts of international law. The International Journal of Human Rights, 24 (7), 913-916, DOI: https://doi.org/10.1080 /13642987.2020.1810477

United Nations. Universal Declaration of Human Rights. (1948).

Yagunov, D. (2010). European Court of Human Rights Practice (Precedents and Comments on Criminal Proceedings). Odesa: Phoenix.

Zavhorodnii, V.A. The legal nature of the decisions of the European Court of Human Rights. Scientific scientist at the International Humanities University. Series: Law, 2015, (1), 19-22. 